\title{
JARINGAN SOSIAL ORGANISASI LESBIAN, BISEXUAL DAN TRANSGENDER: STUDI KASUS ORGANISASI ARDHANARY INSTITUTE DI JAKARTA
}

\author{
Sri Setiawati ${ }^{1}$
}

Received Article: 20 J uni 2017

Accepted Article: 01 Agustus 2017

\begin{abstract}
This paper discusses the social networks that are done by Ardhanary Institute LBT Women (Lesbian, Bisexual, and Transgender) organization in J akarta. With the thes is that the environment in Indonesia are not permissive and cons with the presence of LGBT/LBT this organization even dare to "coming out", if it is not supported by an enabling environment through social networks. This discussion describes the social networks that made this organization, from building social relationships between actors / individuals up with foreign institutions (international) and domestic, as well as with the mass media. As the study of anthropology, then more emphas is on the social network that is descriptive, not at the level of analytics. Data collection technique was not through measurement but more in the process of intensive observations, in-depth interviews and participatory observation. Using an ethnographic feminist approach, where the relationships globally can only be understood in the "real materials interlocked closely in the everyday encounter", namely action and everyday practicewhich became the subject of ethnography research.
\end{abstract}

Conclusions: 1). The social network that is done by Ardhanary Institute organization through a relationship between actors and LBT/LGBT organizations in these areas. Externally also through multiple agencies (domestic and foreign). The actor, who is in this organization as a motivator, facilitator, and inspirator as well as the implications effect "struggling" for the movement of other LBT organizations in Indonesia 2). This organization is actively building a broader network through cooperation with other women's organizations, crisis centers, health care providers, safe houses, legal aid organizations and the National Commission for Women. And build working relationships with law enforcement agencies in providing assistance to victims of LBT violence.

Keywords: LBT women, LGBT, Social Networking, Social Relationships, "Coming Out"

Abstrak

Tulisan ini membahas mengenai jaringan sosial yang dilakukan organisasi LBT Perempuan (Lesbian, Biseksual, Transgender) Ardhanary Institute di J akarta. Dengan tesis bahwa lingkungan di Indonesia yang tidak permisif dan kontra dengan kehadiran LGBT/LBT malah organisasi ini berani untuk "coming out", jika tidak didukung oleh lingkungan kondusif melalui jaringan sosial. Bahasan ini mendeskripsikan jejaring sosial yang dilakukan organisasi ini, mulai dari membangun relasi sosial antar aktor/individu sampai dengan lembaga luar negeri (internasional) dan dalam negeri, termasuk juga dengan media massa. Sebagai kajian antropologi, maka lebih menekankan pada jaringan sosial yang bersifat deskriptif, tidak pada tataran analitik. Teknik pengumpulan data dilakukan tidaklah melalui pengukuran tapi lebih pada proses pengamatan intensif, wawancara mendalam, dan observasi partisipatif.

\footnotetext{
${ }^{1}$ Penulis adalah dosen tetap Jurusan Antropologi FISIP Universitas Andalas
} 
Menggunakan pendekatan etnografi feminis, dimana hubungan-hubungan global hanya dapat dipahami dalam "bahan-bahan nyata yang saling bertaut erat dalam perjumpaan sehari-hari", yaitu tindakan dan praktik sehari-hari yang menjadi bahan dari penelitian etnografi.

Kesimpulan:1). J aringan sosial yang dilakukan organisasi Ardhanary Institute melalui relasi antar aktor serta organisasi LBT/LGBT yang ada di daerah-daerah. Secara eksternal juga melalui beberapa lembaga (dalam dan luar negeri). Aktor yang ada dalam organisasi ini sebagai motivator, fasilitator, serta inspirator yang berimplikasi effek "struggling" bagi pergerakan organisasi LBT lainnya di Indonesia 2). Organisasi ini secara aktif membangun jaringan yang lebih luas melalui kerjasama dengan organisasi-organisasi perempuan lainnya, crisis center, penyedia layanan kesehatan, rumah aman, lembaga bantuan hukum dan Komnas Perempuan. Serta membangun relasi kerja dengan para penegak hukum dalam memberikan pendampingan bagi LBT korban kekerasan.

\section{Kata-kata Kunci: LBT Perempuan, LGBT, J aringan Sosial, Relasi Sosial, “Coming Out”}

\section{A. Pendahuluan}

uatu masyarakat dapat dipandang Sebagai jaringan hubungan sosial antar individu yang sangat kompleks. Jaringan-jaringan hubungan yang terbentuk menjadi penting bagi masyarakat tersebut. Adanya keterbatasan manusia berhubungan dengan semua manusia yang ada, maka individu belajar melalui pengalamannya untuk memilih dan mengembangkan hubu ngan-hubungan sosial yang tersedia dalam masyarakat, disesuaikan dengan kebutu han-kebutuhan yang ada pada individu yang bersangkutan. Manusia tidak selalu menggunakan semua hubungan sosial yang dimilikinya dalam mencapai tujuan-tujuan nya, tetapi disesuaikan dengan ruang dan waktu atau konteks sosialnya (Agusyanto, 2007:30).

Dalam kenyataannya, jaringanjaringan hubungan sosial ini sangat kompleks dan saling tumpang tindih atau saling memotong sehingga untuk kepenti ngan analisis Barnes (1969) membedakan antara jaringan total dan jaringan partial ${ }^{2}$. Sedangkan Mitchell (1969) konsep jaringan sosial bisa digunakan untuk memahami

\footnotetext{
2 Jaringan total digunakan untuk menyebut jaringan sosial yang kompleks. Menurut Barnes : "....apapun hal itu yang merupakan abstrak pertama dari semua realitas, semua yang ada di dalamnya tentang informasi seluruh kehidupan sosial komuniti tersebut dan saling keterhubungannya (Barnes,1969:56). Jaringan partial adalah semua inti (hasil penyaringan) dari jaringan total yang didasarkan pada kriteriakriteria yang bisa diterapkan/dipakai terhadap keseluruhan jaringan (Barnes, 1969:57).
}

perilaku orang-orang (persons) di dalam situasi-situasi yang spesifik ${ }^{3}$.

Dalam kajian ini, jaringan sosial merupakan sebagai relasi yang terjadi dengan pihak-pihak tertentu yang men dukung dan memfasilitasi organisasi LBT Ardhanary Institute. Lebih khusus mendeskripsikan jaringan kerja dilakukan aktor-aktor dalam organisasi ini baik secara kelembagaan maupun individual, yang selama ini telah bekerja sama mendukung dan memfasilitasi berbagai program kegiatan organisasi tersebut.

Jejaring sosial dimaknai organisasi ini merupakan keterlibatan semua pihak yang bekerja sama untuk memperjuangkan suatu isu yang sama, baik individu maupun organisasi yang fokus bekerja meski berbeda tetapi masih berkaitan dan mau ikut terlibat, serta pihak pemerintah yang bertanggung jawab untuk isu tersebut dan bisa diajak bekerja sama ${ }^{4}$ Hal ini memperlihatkan, bahwa dalam jaringan sosial atau jejaring mencakup adanya relasi kerja sama baik secara langsung maupun tidak langsung dilakukan aktor-aktor dalam memperjuangkan isu yang sama yakni isu keragaman gender dan seksualitas perempuan di Indonesia.

Bagi organisasi LBT Ardhanary Institute jejaring sangatlah penting, sama seperti organisasi lainnya. Dengan asumsi tidak ada masalah yang bisa diselesaikan oleh satu individu ataupun satu organisasi

\footnotetext{
${ }^{3}$ Lihat Ruddy Agusyanto, Jaringan Sosial dalam Organisasi, 2007.

${ }^{4}$ Hasil wawancara dengan Ino ( AI ) 10 Mei

2016 di Ardhanary Institute Jakarta.
} 
manapun hebatnya. Untuk mendorong perubahan sosial, misalnya dalam bidang keragaman gender dan seksualitas perem puan, dibutuhkan kerja sama dan bantuan dari berbagai pihak, baik untuk turut menyebarkan informasi dan edukasi yang benar maupun untuk mendorong lahirnya kebijakan.

Ardhanary Institute merupakan organisasi yang mengusung isu-isu ber kaitan dengan Lesbian, Biseksual dan Transgender (LBT), khususnya keragaman gender dan seksualitas perempuan di Indonesia. Organisasi ini terbangun dari suatu keputusan yang disadari atau disengaja oleh individu atau sekumpulan individu untuk mencapai tujuan-tujuan tertentu melalui kerja sama dengan disiplin yang tinggi dari sumber daya manusia dan material. Dengan kata lain, organisasi ini akan selalu melibatkan suatu kerjasama sejumlah sumber daya manusia dan sumber daya fisik ke dalam suatu mekanisme kontrol, monitoring dan koordinasi yang rapi agar tujuan-tujuan tertentu atau target-target organisasi mampu dicapai.

Dalam perjalanan waktu, organisasi ini berkembang menjadi semakin kompleks seiring dengan perubahan faktor eksternal yang ada. Apalagi di era globalisasi ini, jika tidak mampu selalu menyesuaikan diri dengan perubahan kondisi yang ada tidaklah mustahil menjadi semakin sulit untuk mencapai tujuan-tujuan organisasi yang telah ditetapkan ${ }^{5}$. Mengingat kondisi sekarang isu LGBT di Indonesia semakin santer diperbincangkan berbagai kalangan, otomatis juga mempengaruhi organisasi ini untuk menyikapinya.

Dalam menyikapi hal tersebut, jaringan sosial yang sudah terjalin dengan berbagai pihak, sebisa mungkin tetap dipertahankan organisasi ini. Tetap melakukan negosiasi kepada masyarakat dan memberikan informasi pengetahuan mengenai keragaman gender dan sek sualitas. Hal tersebut tidak bisa dilakukan organisasi ini sendiri melainkan harus menjalin kerjasama dengan pihak lainnya. Organisasi ini harus bisa melihat peluang-

5 Lihat Katya Gardner dan David Lewis. Antropologi, Pembangunan dan Tantangan Pascamodern (terj.) Maumere: Penerbit Ledkro.2005. peluang yang terbuka dalam masyarakat dalam membangun cara pandang yang baru dan lebih menghargai individu satu dengan yang lainnya. Misalnya dalam bersosialisasi dengan tetangga sekitar yang merupakan bagian dari masyarakat, menjalin hubungan yang baik merupakan salah satu strategi agar diterima setidaknya dalam hal kebebasan berekspresi yaitu mengenalkan kepada tetangga sekitar bahwa tidak semua perempuan itu feminine melainkan ada yang tomboy.

Organisasi ini berjejaring baik secara personal (individu) maupun lembaga, di dalam maupun skala internasional. Namun, fokus kerjanya memang lebih banyak di dalam negeri. Jejaring organisasi ini, antara lain adalah organisasi donor, organisasi LBT lain, organisasi LGBT, organisasi perempuan, organisasi HAM, lembaga bantuan hukum, individu (expert) di bidang hukum dan seksualitas, akademisi, serta individu dari komunitas LBT/ LGBT.

\section{B. Jejaring Ardhanary Institute dengan Lembaga Internasional}

Deriode pasca reformasi merupakan kebangkitan kaum lesbian untuk tampil di ruang publik ("coming out"),

termasuk juga organisasi Ardhanary Institute. Periode inilah telah terjadi transformasi strategi gerakan dimana lesbian menjadi gerakan sosial dan politis yang kuat dan melembaga. Bukan hanya dengan lahirnya organisasi-organisasi les bian melainkan kerja jaringan dan dukungan dari kelompok-kelompok non LBT, seperti kelompok perempuan, HAM dan pluralisme. Bahkan gerakan lesbian di Indonesia pasca reformasi telah berkontribusi cukup besar dalam mendorong pemajuan HAM (nasional dan internasional) melalui pelibatan mereka dalam gerakan LBT perempuan, HAM dan LGBT.

Keaktifan dan menguatnya jaringan kerja menunjukkan bahwa kesadaran kelom pok lesbian atas hak-haknya semakin tinggi dibarengi dengan kebangkitan dalam memperjuangkan hak-hak tersebut. Kemam puan berorganisasi meningkat pesat setelah belajar dari berbagai kasus kegagalan maupun keberhasilan menggalang komu nitas dan jaringan dari berbagai gerakan lesbian sebelumnya. 
Keberadaan LBT/LGBT tidak bisa dinafikan dalam kehidupan berbangsa dan bernegara, termasuk Indonesia. Di tingkat internasional, para tokoh telah memberikan perhatian yang serius terhadap isu LGBT/LBT. Hillary Clinton dalam sebuah pertemuan Konferensi Tingkat Tinggi (KTT) dunia di PBB mengatakan bahwa LGBT bukanlah temuan dari dunia barat melainkan kenyataan dalam kehidupan dan sejarah manusia ${ }^{6}$. Bahkan Sekretaris Jenderal PBB, Ban Ki Moon (2010) mengatakan bahwa :

"Sebagai laki-laki dan perempuan yang mempunyai hati nurani, kita menolak diskriminasi secara umum, dan khususnya diskriminasi berdasarkan orientasi seksual dan identitas gender. Apabila seseorang diserang, diperla kukan dengan kejam, atau dipenjara kan karena orientasi seksual mereka, kita harus bersuara .... Hari ini, banyak bangsa mempunyai konstitusi modern yang menjamin hak-hak dasar dan kebebasan. Akan tetapi, homoseksual masih dianggap kriminal di lebih dari 70 negara. Hal ini tidak benar. Benar, kita mengakui bahwa sikap sosial masih berperan kuat. Benar, perubahan sosial terjadi seiring dengan berjalannya waktu. Namun, janganlah ada kebingu ngan ketika terjadi ketegangan antara sikap sosial dan hak asasi manusia universal, maka haklah yang harus dimenangkan. Penolakan secara priba di, bahkan penolakan masyarakat bukan merupakan alasan untuk menan gkap, menahan, memenjarakan, mele cehkan, ataupun menyiksa seseorang, tidak pernah"

Dari pernyataan Sekjen PBB di atas memperlihatkan secara kelembagaan inter nasional PBB juga menyikapi perlakuan di beberapa negara terhadap kaum LGBT. Diskriminasi yang berdasarkan orientasi

\footnotetext{
${ }^{6}$ Our Voice Zine, Hillary Clinton: Homoseksual Bukan Soal Barat, Volume 5, (2011).

7 United Nations, "Ending Violence and Criminal Sanctions Based on Sexual Orientation, Gender Identity; Confront prejudice, speak out against violence, Secretary-General says at event on 'Ending Sanctions Based on Sexual Orientation, Gender Identity", 10 Desember 2010, (on line) http://www.un.org/News/Press/docs/2010/sgsm 13311.doc.htm,diakses 15 Januari 2015.
}

seksual dan identitas gender tidak dibenarkan karena menyangkut hak asasi manusia secara universal. Reaksi senada juga diberikan oleh Hillary Clinton akan isu LGBT pada sebuah pertemuan tingkat internasional.

Berkaitan dengan itu, jaringan sosial bagi organisasi Ardhanary Institute sanga tlah penting, mewujudkan program kegiatan yang telah direncanakan khususnya advokasi terhadap LBT perempuan dan upaya-upaya untuk menghilang kan stigma masyarakat tentang LBT/LGBT. Berbagai program kegiatan dilakukan organisasi ini melibatkan atau kerjasama dengan pihak lain. Sebagaimana menurut Mitchell (1969), pentingnya melihat jaringanjaringan hubungan personal untuk memahami perilaku masyarakat. Keterikatan individu-individu dalam hubungan-hubungan sosial adalah pencerminan dirinya sebagai makhluk sosial, sebagai upaya untuk mempertahankan keberadaannya. Memba ngun jaringan melalui individu dan komunitas LBT/LGBT, organisasi yang bergerak dalam isu-isu perempuan, hak asasi manusia termasuk media dan agama (organisasi/kelembagaan maupun individu). Satu hal jaringan kerja yang terpenting dalam organisasi LBT yakni dengan lembaga donor internasional. Kemampuan Ardhanary Institute untuk tetap bertahan, melalui berbagai strategi dalam rangka menghadapi arus globalisasi yang membawa serta nilai-nilai budaya asing dan sekuler untuk tidak tunduk dengan mudah pada kepentingan donatur internasional, yang memiliki andil dalam membiayai kelangsungan hidup organisasinya.

Pada umumnya organisasi LGBT mendapatkan pendanaan dari lembaga donor internasional seperti USAID, AusAID, UNAIDS dan UNFPA. Ada sejumlah negara Eropa yang pernah mendanai program jangka pendek, terutama berkaitan dengan HAM LGBT. Pendanaan paling luas dan sistematis disediakan Hivos, sebuah organisasi Belanda, terkadang bersumber dari pemerintah Belanda. Negara Belanda gencar melakukan kampanye yang di motori oleh HIVOS kepada masyarakat Belanda supaya mereka mendukung perjuangan hak-hak LGBT di seluruh dunia. Kemudian Ford Foundation bergabung dengan Hivos dalam menyediakan sumber pendanaan bagi organisasi-organisasi LGBT. UNDP dan 
USAID meluncurkan prakarsa "Being LGBT in ASIA" pada tanggal 10 Desember 2012. Diantara negara yang menjadi fokus program ini adalah China, Indonesia, Philipina dan Thailand ${ }^{8}$. Berdasarkan dokumen UNDP program "Being LGBT in Asia" fase 2 dijalankan dari Desember 2014 hingga September 2017 dengan anggaran US\$ 8 juta?.

Organisasi Ardhanary Institute menjadi bahagian dari program di atas. Pada bulan Oktober 2014 Ardhanary Institute mendapatkan kepercayaan dalam penyerahan kunci petisi diberikan oleh Direktur HIVOS ROSEA Jan Jaap Kleinrensink. Saat itu jumlah tanda tangan dukungan sudah mencapai 8000 lebih, harapannya bisa mencapai 10.000 dukungan. Petisi dukungan dilakukan secara online melalui www.freetobeme.nl. Tahun 2006 salah seorang aktivis organisasi ini masuk sebagai bagian dari Women Human Rights Defender yang terlibat aktif dalam perumusan buku konsultasi pada PBB.

Perjuangan LGBT termasuk kaum lesbian dalam menghadapi sikap-sikap homofobia dan transfobia di seluruh sektor kehidupan baik dalam bermasyarakat maupun bernegara, untuk menjadi dirinya sendiri dengan bebas memiliki perasaan cinta. Slogan Free to be me, Kami bekerja, kami tidak sendiri, kami berhak menjadi diri kami sendiri, adalah kampanye yang dilakukan oleh HIVOS melalui penyebaran petisi dukungan dan donasi kepada warga Belanda yang selanjutnya akan digunakan oleh HIVOS untuk mendukung organisasiorganisasi LGBT di seluruh dunia. HIVOS juga mengundang beberapa perwakilan aktivis LGBT untuk menerima petisi melalui simbol kunci berwarna pink bertuliskan: Free to Be Me, Dutch citizen spoke out in favour of freedom in love and the right for all LGBT's in Indonesia to be themselves.

Pada tahun 2011 organisasi Al menjadi anggota dari Asia-Pasific Women Law and Development (APWLD), meru pakan organisasi lesbian Indonesia pertama

\footnotetext{
${ }^{8} \mathrm{https//www.usaid.gov/asia-regional/being-lgbt-}$ asia

${ }^{9} \mathrm{http} / \mathrm{www} . \mathrm{asia}-$

pacific.undp.org/content/rbap/en/hlgbt-inasia.html
}

yang menjadi anggota APWLD dan terlibat aktif mendorong isu hak-hak lesbian terangkat dalam perjuangan APWLD di tingkat regional dan aktif membuat laporan violence Against Women untuk konteks kekerasan terhadap lesbian. Hadir dalam Sidang Persatuan Bangsa-Bangsa untuk laporan implementasi CEDAW Indonesia atau dukungan CEDAW Working Indonesia (CWGI) sebagai perwakilan masyarakat sipil. Kemudian organisasi ini juga kerjasama dengan International Lesbian and Gay Human Rights Commision (ILGHRC) dalam menterjemahkan dan mencetak buku saku tentang Yogyakarta Principles edisi bahasa Indonesia serta melakukan kegiatan launching dengan mengundang aktivis dan organisasi LGBT di seluruh Indonesia.

Salah seorang aktivis organisasi Ardhanary Institute terpilih menjadi board female representative ILGA-ASIA. Tahun 2008 ada empat orang lesbian perwakilan dari Ardhanary Institute, Arus Pelangi, GAYa Nusantara dan Institute Pelangi Perempuan hadir dalam ILGA-Asia Conference di Chiang Mai, Thailand. Hal ini memper lihatkan suatu keberhasilan bagi organisasi lesbian Indonesia yang turut berkontribusi dalam gerakan LBT Internasional. Pada tahun yang sama, lahirlah Forum LGBTIQ Indonesia. Tahun 2010 ILGA-Asia Conferen ce dilaksanakan di Surabaya dimana perwakilan lesbian dari berbagai provinsi maupun dari negara Asia lainnya hadir dengan jumlah yang cukup banyak, walau konferensi itu gagal terlaksana karena penolakan dari kelompok masyarakat yang menggunakan atribut kelompok agama. Capaian lainnya adalah keterlibatan perwakilan lesbian di gerakan ASEAN tahun 2011 dengan mendorong isu SOGI dibahas dalam pertemuan-pertemuan gerakan civil ASEAN.

Penjelasan di atas memperlihatkan keterlibatan organisasi Ardhanary Institute dengan berbagai lembaga atau organisasi internasional, sebagai bentuk jaringan sosial yang telah dilakukannya. Bentuk jaringan sosial ada yang bersifat secara langsung maupun tidak langsung. Secara langsung biasanya dilakukan melalui personal seperti dilakukan Agustine sebagai representatif dari organisasinya. Meskipun posisi Agustine sebagai pemimpin dalam organisa si Ardhanary Institute, namun lembaga 
internasional tetap melihat kapabilitas-nya secara personal. Bagaimanapun "bagusnya" suatu organisasi, jika individu-individu dalam organisasi tersebut tidak memiliki kemam puan relasi yang baik dengan berbagai pihak maka jejaring juga tidak akan terjadi. Peranan aktor dalam jaringan sosial sangatlah penting, apalagi dalam organisasi yang mengusung isu keragaman gender dan seksualitas perempuan.

Dalam organisasi Ardhanary Institu te, sosok aktor yang berperan yakni Agustine. Kehadiran organisasi ini lekat pada sosok Agustine disamping sebagai salah satu pendiri tapi juga menakhodai, tepatnya direktur eksekutif Ardhanary Institute. Berbekal pengalaman akademis di Belle Van Zuylen Universitas Van Amsterdam tahun 2006 belajar isu Gender dan Seksualitas serta koordinator divisi informasi dan dokumentasi di Koalisi Perempuan Indonesia tahun 2000-2009, kemudian koordinator program penguatan kapasitas untuk Gender, Seksualitas dan HIV/AIDS. Bahkan tahun 2010, menjadi konsultan STOP AIDS NOW! For Women and Girls. Sekarang aktif menjadi fasilitator dan pengembangan modul SOGIEB (Sexual Orientation, Gender Identity, Expression and Bodies) serta Keragaman Gender dan Seksualitas.

Di samping itu, aktor lainnya yakni L disamping sebagai pendiri bersama Agustine membesarkan organisasi ini sampai sekarang. L sebagai program manager Ardhanary Institute aktif menulis isu feminis dan hak-hak perempuan untuk blog. Sebelumnya pernah aktif di Yayasan Pemantau Hak Anak (2006-2009). Di organisasi ini menjadi fasilitator Training of Trainer (ToT) dan Advokasi untuk organisasi LGBT, belajar Filsafat di Universitas Driyarkara (2009) dan sekarang belajar di ISIP Universitas Bung Karno. Kedua sosok ini berperan besar dalam organisasi ini, disamping ada beberapa anggotanya .

Kemudian secara tidak langsung biasanya organisasi Al berjejaring melalui lembaga perantara seperti tergabung dalam suatu aliansi atau forum yakni Aliansi Satu Visi dan Forum LGBTI Indonesia. Melalui jejaring dalam forum atau aliansi ini, organisasi Al semakin mendapatkan kekuatan dalam memperjuangkan isu yang sama. Aliansi Satu Visi dan Forum LGBT Indonesia awalnya diinisiasi dan difasilitasi oleh Rudgers WPF Indonesia berkedudukan di Belanda.

\section{Peran Media Sosial Dalam Jejaring}

( ejak tahun 1980-an media cetak di $\longrightarrow$ Indonesia telah menjadi sumber gambaran mengenai lesbian dan gay melalui cerita-cerita mengenai kebebasan gay dan gaya hidup gay di Eropa Amerika. Media cetak juga menciptakan gambaran bahwa kaum lesbian 'yang sebenarnya' adalah perempuan maskulin yang berpasangan dengan perempuan feminin (Gayatri, 1997), cerita-cerita yang ada di Indonesia mengenai lesbian yang mencoba untuk menikah atau hidup bersama kelihatan menjadi pendorong yang pertama kalinya meyakinkan kaum lesbian untuk tinggal bersama. Cerita-cerita tersebut memberikan pandangan mengenai adanya kemungkinan terhadap gaya hidup alternatif untuk pasangan sesama jenis (lihat Blackwood, 1999).

Membahas tentang lesbian di media massa pasca reformasi menjadi topik perhatian yang menarik, khususnya dalam hubungannya dengan feminisme, cinta dan hubungan seksual, perkawinan dan pengasuhan anak. Namun sebelum era reformasi, kondisi lesbian di Indonesia yang diibaratkan oleh salah seorang aktivis LBT seperti 'rahasia sunyi' karena hanya sedikit orang yang mengetahui bagaimana individu maupun kelompok lesbian melakukan serangkaian aksi dalam memunculkan jati dirinya dan melakukan perlawanan atas segala bentuk diskriminasi yang dialami untuk dapat hidup setara dengan manusia lainnya ${ }^{10}$.

Bahkan dalam sebuah Forum Discussion Group tentang "Lesbian dan Media Massa" yang dilaksanakan oleh Ardhanary Institute, salah seorang peserta Eko Bambang Subiyanto mengatakan bahwa media massa lebih tertarik mengangkat isu lesbian sebagai isu yang fenomenal sehingga bernilai komoditi untuk menopang nilai jual media tersebut.

10 Lihat Agustine, Sri dan Evi Lina Sutrisno.(eds.) Mendengar Suara Lesbian Indonesia : Kumpulan Buah Pikir Aktifis Feminis \& Pluralis. Ardhanary Institute - HIVOS ROSEA, 2013. 
Sebagaimana hasil wawancara dengan Agustine dibawah ini :

"Media itu punya peran utama bahkan terlalu berlebih, media itukan bentuk berita yang sangat terus di klik..klik..klik. Biasanya yang paling banyak itu media online karena persaingan ekonomi, makanya mereka perlu menggoreng isu"

Hal ini akan berdampak sekali bagaimana pandangan masyarakat terhadap LGBT karena isunya terus di bombardir sehingga memunculkan "head tricky sense" dalam pikiran masyarakat, yang awalnya masya rakat merespon biasa saja tapi lama-lama menjadi masalah dan bahkan memunculkan rasa kebencian.

Di dunia cyber, muncul pula groupgroup lesbian yang salah satunya beranggotakan hingga 7000 members ${ }^{11}$. Group lesbian di cyber mempunyai karakteristik yang berbeda dengan komuni tas langsung, anggota kebanyakan tidak menggunakan nama asli dan kegiatan berbentuk penguatan identitas sebagai lesbian, mencari pertemanan dan pacar. Saat sekarang jumlah group yang ada di dunia cyber berjumlah 80 dengan namanama senada seperti Belokers, Dunia Koleb, Butchi-Femme Community, Linez Com munity dan lain-lain (Agustine, 2013:208).

Di satu sisi, media massa juga tidak tertarik dengan isu gerakan lesbian karena dinilai tidak seksi atau tidak ada nilai jualnya. Isu seksualitas dan kebingungan identitas yang dialami para lesbian dianggap lebih bernilai jual untuk mendongrak oplah media tersebut. Bahkan yang lebih parah lagi, adanya anggapan lesbianisme sebagai gangguan kejiwaan dianggap lebih menarik terutama diangkat dalam topik rubrik konsultasi seksologi dan psikologi (Kompas, 28 November 1999).

Namun sisi lain, peranan media massa terhadap gerakan lesbian di Indonesia sangatlah memberi pengaruh besar, terutama dalam perjuangan kaum lesbian. Menurut Soukhanov (1996), gera kan diartikan serangkaian aksi dan peristi wa yang berjalan dalam satu kurun waktu dan terlaksana untuk membantu perkemba

\footnotetext{
${ }^{11}$ Lihat

http://www.facebook.com/pages/Belokers/94526 191463 ? fref $=$ ts
}

ngan sebuah prinsip atau kebijakan (dalam Triana, 2007). Pelaku gerakan lesbian didefinisikan sebagai kelompok atau individu yang bersinggungan langsung dengan pergumulan kehidupan sehari-hari sebagai lesbian, bereaksi dan berupaya untuk memunculkan eksistensi sebagai seorang atau sekelompok lesbian, melakukan aksi untuk sebuah perubahan yang membela kepentingan lesbian (Agustine, 2013: 191).

Sejumlah provider internet Indone sia, termasuk di antaranya Telkomsel, sejak beberapa bulan memblokir situs web Komisi Hak Gay dan Lesbian Internasional IGLHRC, karena mengandung "unsur pornografi". Organisasi-organisasi LGBT Lesbian, Gay, Biseks, dan Transgender (waria) Indonesia sepakat membawa kasus ini ke DPR untuk meminta penjelasan lebih lanjut. Setelah penjelasan itu didapat, baru mereka akan menghadap ke Menkominfo yang dikabarkan memerintahkan pemblo kiran IGLHRC. Kasus ini menyebabkan kalangan aktifis LGBT Indonesia yang ada di Jakarta turun ke jalan. Menurut Poedjiati Tan dari organisasi Gay Indonesia Gaya Nusantara kepada Radio Nederland sebagai berikut :

"Tuduhan itu tidak masuk akal...tidak mengerti. Langkah tersebut menunjukkan mereka tidak mengerti tentang gender dan seksualitas. Padahal situssitus itu tidak mengandung pornografi, melainkan memberi informasi,pemerintah yang menin das tidak bisa menghentikan suara-suara LGBT - apakah itu di internet, media atau di jalan. IGLHRC mendukung perjuangan pegiat HAM di Indonesia untuk tetap menjadikan internet seba gai tempat di mana orang bisa bebas berdialog tentang isu-isu HAM dasar, ${ }^{\text {,12 }}$

Menurut mereka, pemblokiran situs web adalah serangan terhadap kebebasan berekspresi. Seringkali pemerintah memakai tuduhan pornografi sebagai alasan untuk menyerang kebebasan berekspresi. Ketidak bebasan LGBT dalam mengeluarkan penda pat merupakan salah satu kemungkinan

${ }^{12}$ Lihat poskotanews.com

159 | P a g e 
dampak dari undang-undang pornografi. Kekhawatiran para pengambil kebijakan terhadap LGBT memberikan pengetahuan dan wawasan tentang seksualitas, akan diartikan mengandung konten porno. Ketidakpahaman serta wawasan yang masih terbatas tentang gender dan seksualitas terlihat dalam kasus ini, sebagaimana disampaikan juru bicara Telkomsel kepada The Jakarta Globe, Ricardo Indra dibawah ini:

"Telkomsel memblokir situs web
pornografi yang tercantum dalam
daftar alamat URL. Daftar URL ini
direkomendasi Kementerian
Informasi dan Komunikasi, yang
memonitor dan memperbaharui
secara teratur daftar berisi situs web
pornografi tersebut."13

Di dalam situs web IGLHRC sendiri tercantum bahwa organisasi ini melakukan advokasi HAM untuk orang-orang yang mengalami diskriminasi atau pelecehan karena orientasi seksual, gender atau ekspresi. Menanggapi pemblokiran situs web IGLHRC, organisasi-organisasi LGBT di Indonesia mengajukan surat komplain ke Menkominfo dan DPR, serta meminta agar situs web tersebut dibuka kembali.

Berdasarkan kasus diatas, ada 2 hal yang bisa kita pahami yakni : ketidak mengertian dan kebebasan untuk berdialog. Anggapan kalangan LGBT bahwa pemerintah selama ini sering memakai tuduhan pornografi atas situs-situs yang dikelola LGBT untuk menekan dan membatasi kekebasan berekspresi kalangan ini. Bahkan lebih tendensius lagi kalangan ini menyatakan pemerintah telah menindas mereka, meskipun demikian mereka tidak akan pernah berhenti untuk menyuarakan kepentingan LGBT.

Menurut Hartoyo dari Our Save bahwa sekarang semakin banyak akun Twitter yang berkaitan dengan homo seksualitas. Akun-akun itu berpengikut ribuan hingga puluhan ribu. Beberapa digunakan sebagai media penunjang gairah, beberapa lainnya sengaja dibuat penuh sensasi demi mendulang sebanyakbanyaknya follower untuk dijual kemudian. Banyak akun dengan konsentrasi homoseksual justru menayangkan konten

13 Poskotanews.com yang amat hetero-normatif. Ternyata dari beberapa akun itu dikelola oleh heteroseksual, disebabkan akun gay cende rung mudah mendapatkan ba nyak follower dalam waktu singkat. Semakin banyak follower yang didapat, nilai jual akun itu semakin mening kat. Perjuangan kaum homoseksual termasuk lesbian untuk semakin banyak bersuara akan semakin didengar. Namun apa jadinya jika banyak orang berkumpul baik seca ra offline maupun online di tempat yang salah. Homoseksual merupakan minoritas dan kebebasan orientasi seksual masih menjadi nomor sekian untuk dipentingkan di negeri ini. Sebagaimana disampaikan Hartoyo (Our Voice) dibawah ini :

"Sebagai salah seorang dari sekian banyak homoseksual yang tersebar di Indonesia, tentu saya ingin orangorang yang senasib dengan saya mendapatkan tempat setara dengan mereka-yang-disebut-normal. Butuh proses panjang mengangkat kaum LGBT ke posisi setara dengan para heteroseksual. Apalagi jika semakin banyak LGBT yang enggan keluar dari zona nyamannya untuk mau belajar bahwa identitas mereka lebih dari sekadar perbedaan orientasi seksual". ${ }^{14}$

Namun masih ada pihak-pihak yang terus konsisten berusaha meningkatkan peneri maan dan kepercayaan diri para LGBT dengan membuat dan mengelola situs dengan konten yang lebih dari sekadar persoalan hubungan dan berahi.

Melihat hal tersebut, maka organisasi Al berinisiatif untuk melakukan program yang berkaitan dengan media. Organisasi Al telah membuat "Modul Panduan Media Meliput LGBT" bekerjasama dengan Yayasan Jurnal Perempuan (YJP) dan Hivos, yang diterbitkan tahun 2015. Agustine dari Al termasuk salah satu tim penyusun modul tersebut, selain itu ada Gadis Arivia dan Dewi Candraningrum dari Yayasan Jurnal Perempuan. Modul ini dibuat sebagai sumbangan untuk panduan media dalam meliput LGBT, yang selama ini peliputan media tidak berimbang dan bahkan diskriminatif terhadap kaum LGBT.

\footnotetext{
14 Hasil Wawancara dengan Hartoyo dari Our Voice, tanggal 27 Mei 2014 di FISIP Universitas Indonesia.
} 
Modul ini diawali dengan memuat daftar istilah kata dan bahasa sebagai pintu masuk memahami LGBT, kemudian isu-isu sosial politik budaya yang diskriminasi dan diakhiri bahasan panduan meliput.

Pada tahun 2015 melalui jejaring berbagai media khususnya bersama lembaga AJI (Aliansi Jurnalis Independen) Indonesia, Al melakukan kerjasama melalui program yang bernama Fellowship Jurnalist. Menurut Agustine :

"Jadi kita melatih jurnalis-jurnalis yang meliput isu LGBT secara benar faktual..tidak melakukan pembelaan tapi mereka tidak keluar dari kode etik jurnalis. Prinsip keadilan dengan AJI Indonesia, mereka dilatih cukup panjang, lalu mereka itu membuat liputan-liputan yang tengah ramai nya, bagaimana mereka meliput dengan netral"15

Kegiatan ini dilakukan selama 6 bulan dengan melibatkan jejaring dengan berbagai media massa di 5 kota di Indonesia yakni : Medan, Surabaya, Jakarta, Makasar dan Bali. Sebelum dilakukan pelatihan bagi para jurnalis dari berbagai media (televisi, majalah, tabloid dan radio) mereka melakukan penelitian terlebih dahulu dengan mengumpulkan berbagai peliputan yang telah dipublikasikan sebelum 3 bulan terakhir. Mengumpulkan dengan mengun jungi perpustakaan negara, memfoto-copy dan memasukkan data dalam format yang telah disetting oleh AJI Indonesia. Setelah itu barulah mereka melakukan training atau pelatihan pada jurnalis yang berjumlah 68 orang jurnalis. Menurut Agustine, dengan diadakannya pelatihan ini minimal $10 \%$ pemberitaan yang positif tentang LGBT ada, yang selama beberapa bulan terakhir ini berita buruk tentang LGBT terus muncul dan diskriminatif. Misalnya : pemberitaan tentang kasus kriminal seharusnya diliput krimi nalitas, bukan orientasi seksual dari pelaku tersebut menjadi topik utamanya.

Menurut Agustine, gerakan lesbian pasca reformasi menekankan pada strategi politik 'come out' dan advocacy, antara lain dengan pendeklarasian organisasi atau kelompok lesbian di hadapan publik dan

${ }^{15}$ Hasil wawancara dengan Agustine ( rdhanary Institute ) Hari Jumat, 20 Mei 2016 di FKM Universitas Indonesia. kemunculan individu-individu lesbian yang cukup sering di berbagai media massa cetak maupun elektronik untuk mengkampa nyekan hak-hak mereka. Bahkan mulai 2009 setelah sosial media marak, baik individu, kelompok maupun organisasi lesbian semakin visible, ditandai dengan lahirnya berbagai organisasi, blog-blog individu khusus isu lesbian dan group-group online dari berbagai provinsi di Indonesia. Pada tahun yang sama, seluruh organisasi lesbian memperluas kelompoknya menjadi kelom pok lesbian, biseksual dan transgender female to male (priawan) atau disebut kelompok LBT. Dengan demikian gerakan lesbian (LBT) tidak lagi menjadi sebuah gerakan yang ekslusif atau tertutup (in the closet) melainkan menjadi gerakan inklusif, terbuka (coming out) dan politis. Mereka memunculkan identitas lesbian sebagai identitas politik dan dengan demikian menandai kelahiran gerakan lesbian yang berbeda dengan gerakan sebelumnya ${ }^{16}$.

\section{Jejaring Ardhanary Institute Dengan Organisasi Lainnya}

Obagai organisasi perempuan, orga nisasi Al juga berusaha mengembang - kan organisasi melalui strategi advokasinya. Strategi tersebut biasanya sangat terkait dengan pertimbanganpertimbangan politik dan situasi sosial pada zamannya. Organisasi perempuan yang memilih untuk terlibat dalam kerja berjaringan, berupaya untuk belajar dari pengalaman kerja berjaringan sebelumnya, dan lebih cermat memperhatikan momentum politik serta menghitung faktor peluang dan hambatan dalam memperjuangkan suatu isu. Faktor lain yang paling menentukan keberhasilan kerja berjaringan adalah kesadaran bersama untuk menyepakati isu yang akan diperjuangkan bersama, dengan menanggalkan kepentingan individual organisasi ${ }^{17}$.

${ }^{16}$ Hasil wawancara dengan Agustine (Ardhanary Institute), Hari Jumat, 20 Mei 2016 di FKM

Universitas Indonesia.

${ }^{17}$ Lihat Edriana Noerdin, Organisasi Perempuan di Tengah Keterbukaan Politik, dalam Afirmasi Jurnal Pengembangan Pemikiran Feminis.Vol.02,Januari 2013. Penerbit Women Research Institute, Jakarta. 
Awalnya jejaring organisasi Al dengan organisasi perempuan dimulai saat masih merupakan cikal bakal kelompok kepentingan di Koalisi Perempuan Indonesia (KPI). Saat itu KPI memiliki jejaring dengan berbagai lembaga maupun person baik dalam negeri maupun internasional. Setelah Al terbentuk, jejaring itu masih tetap dilanjutkan karena Al sebagai organisasi perempuan yang memiliki visi dan misi terhadap kepentingan perempuan umumnya dan kepentingan lesbian khususnya. Seperti dengan Hivos, masih tetap melakukan kerjasama berbagai program dilakukan baik secara finansial maupun dalam bentuk fasilitas lainnya.

Selain itu juga ada organisasi perempuan yakni Solidaritas Perempuan (SP), yang sampai sekarang masih tetap kerjasama dengan Al. Kedekatan organisasi Al dengan SP ini disebabkan kesejarahan berdiri kedua organisasi ini memiliki pendiri yang sama yakni NK. Dalam organisasi SP, NK merupakan salah satu pendiri dan Dewan Pengurus 1990-1993 dengan posisi sebagai wakil ketua dan pada masa transisi sebagai ketua. Dalam organisasi Al, NK merupakan orang yang berperan penting mulai dari lahir sampai berkembangnya organisasi ini. Saat NK sebagai Sekjen di Koalisi Perempuan Indonesia, organisasi Al saat itu belum terbentuk, namun pionir di mulai dari sektor 15 di KPI sampai pada kelompok kepentingan Lesbian, Biseksual dan Transgender. Jejaring yang ada pada NK kemudian direkomendasikan ke organisasi Al untuk melanjutkan kerjasama dengan lembaga tersebut. Secara struktur organisasi Al, NK sebagai advisor yang memberikan dukungan jejaring melalui lembaga internasional secara personal.

Ardhanary Institute menyadari pentingnya berjejaring terutama jaringan kerja dengan organisasi-organisasi perem puan, baik yang berskala nasional maupun di daerah. Melalui jaringan kerja yang semakin kuat dalam advokasi maka otomatis organisasi juga kuat. Organisasi ini melakukan jaringan kerjasama dengan berbagai lembaga, yang pada dasarnya berkaitan dengan pelaksanaan program kegiatan. Seperti program kegiatan LBT Crisis Center, Ardhanary Institute menyediakan tempat perlindungan semen tara untuk korban KDRT yakni Rumah Aman. Rumah ini bersifat rahasia, terbatas dan memiliki aturan ketat yang wajib diikuti. Jika membutuhkan, hubungi polisi, pendamping hukum, atau pendamping psikologis. Maka lembaga yang terlibat adalah :

- Lembaga Bantuan Hukum (LBH) yang memiliki pengacara atau konselor hukum yang terlatih menangani kasus KDRT dengan biaya yang cukup terjangkau. Layanan yang diberikan berupa : konsultasi atau nasehat hu kum, mendampingi penyelesaian kasus tanpa melalui jalur hukum, mendam pingi penyelesaian kasus melalui jalur hukum, baik pidana maupun perdata.

- Lembaga Pusat Pelayanan Terpadu Pemberdayaan Perempuan dan Anak (P2TP2A) yang merupakan pusat kegiatan yang menyediakan layanan informasi, konsultasi psikologis dan hukum, pendampingan dan advokasi, pelayanan medis, serta rumah aman, bagi perempuan dan anak. P2TP2A ada di tiap tingkat provinsi.

- Pusat Krisis Terpadu (PKT) dan Pusat Pelayanan Terpadu (PPT), di PKT dan PPT terdapat tenaga medis yang terlatih yang terbiasa menghadapi kasus KDRT.Layanan yang diberikan berupa : pengobatan untuk luka fisik, membuat laporan pemeriksaan medis (visum et repertum), dan memberikan layanan konseling psikologis. PKT umumnya terdapat di rumah sakit besar di kota besar. Sementara PPT adalah unit yang terdapat di Rumah Sakit Polisi.

Salah satu jaringan kerja organisasi Al yakni kegiatan penguatan kapasitas melalui pelatihan berseri untuk focal point yang telah dilakukan sejak tahun 2017-2010.

Organisasi Al melakukan jaringan kerja dengan Komnas Perempuan, yakni pada tahun 2006 melalui jaringan kerja dengan Asia-Pasific Women Law and Development, Komnas Perempuan berhasil memasukkan seorang aktivis LGBT Indonesia dari organisasi Al sebagai bagian dari Women Human Rights Defender yang terlibat aktif dalam perumusan buku konsultasi yang akan diusulkan kepada PBB.

Selanjutnya organisasi Al bekerja sama dengan lembaga Rutgers WPF Indonesia yang berpusat di Belanda. Melalui berbagai program kegiatan mulai dari 
penerbitan beberapa tulisan, workshop atau pelatihan, seminar, advokasi dan seba gainya. Apabila kita lihat dari visi, misi dan tujuan kehadiran lembaga Rutgers WPF Indonesia akan terlihat korelasi dengan visi, misi dan tujuan dari organisasi Al.

Rutgers WPF Indonesia memfo kuskan pada bidang kesehatan reproduksi, seksualitas, dan hak asasi manusia. Rutgers WPF Indonesia melihat seksualitas manusia dan kesehatan reproduksi dalam kacamata yag positif untuk mewujudkan Indonesia yang bebas dari kekerasan. Lembaga ini bekerja sebagai organisasi perantara bagi pemerintah dan pemangku kepentingan di Indonesia dengan memberikan bantuan finansial dan teknis melalui transfer pengetahuan, mengembangkan dan me ngimplementasikan intervensi kesehatan reproduksi, seksualitas, dan penang gulangan kekerasan berbasis gender dan seksualitas (SGBV) yang komprehensif, efektif dan inovatif, berdasarkan pendekatan partisipatif, untuk mencapai tatanan sosial yang setara, adil dan menghargai hak asasi manusia terutama untuk anak, remaja, perempuan dan kelompok marjinal lainnya ${ }^{18}$. Lembaga yang didanai dari beberapa lembaga donor yakni : Dance4life, UNI EROPAH, PSO, Kementerian Luar Negeri Belanda dan CORDAID.

Organisasi Al tergabung dalam Aliansi Satu Visi (ASV). Aliansi ini berdiri Desember 2010 yang mempunyai 14 lembaga dan mengusung dua isu besar yakni SRHR dan SGBV. SRHR yang disederhanakan sebagai isu mengenai kesehatan reproduksi (Kespro) sedangkan SGBV mengenai isu seputar kekerasan dalam rumah tangga (KDRT). Rutdgers WPF Indonesia bersama mitra membangun kemitraan untuk mengangkat kedua isu tersebut sebagai prioritas dalam pembangunan manusia Indonesia. Memfa silitasi mitra untuk membangun Aliansi yang bernama Aliansi Satu Visi, memiliki visi dan misi hingga perencanaan strategis sampai tahun 2014. Salah satu anggota Aliansi Satu Visi yakni Ardhanary Institute, disamping anggota lainnya seperti : Cahaya Perem puan WCC, Mitra Aksi, SIKOK, PKBI Daerah Lampung, Yayasan Pelita IImu, Rifka

18 www.rutgerswpfindo.org
Annisa, PKBI DKI Jakarta, PKBI DIY, GWLINA dan RAHIMA, PKBI Jatim, ARI (Aliansi Remaja Independen), PKBI Papua, PKBI Jambi dan Rudgers WPF Indonesia ${ }^{19}$.

Capaian Aliansi Satu Visi (ASV) ini adalah : Pelibatan kelompok muda dengan memfasilitasi pelatihan advokat SRHR dan pelaksanaan Forum Remaja Nasional oleh ASV Muda. Hasil dari pelatihan dan forum ini adalah terbentuknya ASV Muda yang lebih solid untuk mengadvokasi di tingkat nasional, advokasi internasional dalam Global Youth Forum, Penyusunan Pedoman Pelayanan Kesehatan Seks Reproduksi Ramah Remaja (PKSR-2R), Peringatan Hari Kesehatan Seksual Sedunia.

Pada tanggal 9 sampai 14 April 2012 ASV menyelenggarakan Renstra di Jakarta Pusat, yang dihadiri oleh 14 orang perwakilan setiap anggota lembaganya yang ada di Indonesia yakni : Yayasan Pelita IImu, Perkumpulan Keluarga Berencana Indonesia (PKBI) DKI Jakarta,GWL INA, Ardhanary Institute, PKBI Yogyakarta, Rifka Annisa, Rahima, PKBI Lampung, SIKOKJambi, PKBI Jatim, Women Crisis Centre (WCC) Bengkulu dan Aliansi Remaja Independen (ARI). Selain itu dihadiri dari Ruthgers WPF dan 2 orang fasilitator yakni Jamal dan Bayu. Renstra untuk 3 tahun ke depan dihasilkan antara lain : perbaikan misi, visi dan tujuan ASV, dan menentukan arah kegiatan ASV di tingkat nasional. Kemudian Agustine terpilih sebagai ketua ASV menggantikan Harry dari PKBI DKI Jakarta. Sebelumnya Agustine dalam ASV sebagai sekretaris. Sebagai ketua, Agustine semakin memperluas jejaringnya terutama memperkuat advokasi. ASV memfokuskan advokasi yaitu CSE (comprehensive sexua lity for education) dan CSS (comprehensive sexuality for service). Untuk kepentingan advokasi ada beberapa sasaran yang dilakukan ASV yaitu : primer pada eksekutif dan legislatif sebagai pembuat kebijakan sekaligus ranah HAM sebagai pemangku kewajiban. Kemudian sasaran sekunder yaitu para tokoh agama di level nasional seperti NU, Muhammadyah dan MUI yang punya power, media massa dan media elektronik, dan sebagainya. Untuk sasaran tersier akan mengarah pada kelompok profesi seperti akademisi, IBI (Ikatan Bidan

${ }^{19}$ https://issuu.com 
Indonesia), IDI (Ikatan Dokter Indonesia), MGMP (Musyawarah Guru Mata Pelajaran), kelompok remaja, dan sebagainya. ${ }^{20}$ Jejaring organisasi Al dengan beberapa organisasi LGBT/LBT biasanya mengusung isu yang sama. Berkaitan dengan program kegiatan seperti penguatan kelembagaan organisasi LBT, Al mengada kan workshop penguatan institusional bagi organisasi LBT atas dukungan HIVOS Southeast Asia. Kegiatan ini melibatkan beberapa jejaring organisasi LBT yang ada di beberapa daerah seperti: Talita Kum Solo, Persatuan Tomboy Pontianak (Pertopan), Komunitas Perempuan Sehati (Kopi Kediri), Tunas Pelangi Padang, Gendhis LBT Lampung, Gamacca LBT Muda Makasar, BFF dan komunitas LBT Jakarta Utara.

Peringatan Hari International Penghapusan Homofobia dan Transfobia dirayakan setiap tahun oleh Ardhanary Institute (AI) bersama Forum LGBTIQ Indonesia. Untuk kegiatan IDAHO 2012 selain dilaksanakan di Jakarta, Al juga mensupport jaringan kerja LBT di berbagai daerah untuk melaksanakan kegiatan IDAHO. Kegiatan yang dilakukan Al dengan Forum LGBTIQ Indonesia wilayah Jakarta mulai dari roadshow to campus, Pawai Warna Warni LGBTIQ, Drag King/Queen dan Jalan Santai.

Pada tahun 2016, organisasi Al tidak bergabung lagi dengan Forum LGBTIQ Indonesia dalam pelaksanaan kegiatan IDAHO, melainkan bergabung dengan orga nisasi Suara Perempuan (SP). Berhubung ada beberapa hal yang tidak disepakati Al berkaitan dengan pernyataan bersama yang telah dikeluarkan Forum LGBTIQ Indonesia berkenaan dengan menggugat pernyataan pejabat negara. Namun satu sisi, Al masih menjadi anggota forum tersebut, mau tak mau jejaring yang telah ada juga dipertahankan, di sisi lain organisasi Al mempunyai strategi advokasi yang berbeda dengan forum. Sebagaimana dinyatakan Agustine di bawah ini :

"Kalau itu kan karena kita anggota forum lalu buat pernyataan bersama.

Walaupun sebenarnya ada beberapa point Al tidak sepakat misalnya. Kan kalau namanya strategi advokasi itu gak harus selalu menuntut dan

${ }^{20}$ Lihat www.rahima.or.id menyerang tapi itu dialog proses dialogis ya...seperti itu advokasi di Al. Kalau kita di Al beda gimana daripada merugikan semua pihakkan dan lagi kitakan tidak mau terlalu publishpublish di FB gitu.ltu bukan karena kita takut apa,tapi kan kita ingat Suara Perempuan aja masih trauma yang kemarin-kemarin, juga jangan terlalu gini, kita menghormati SP. Namanya berjejaringan-kan mengakomodir banyak hal,21

harus

Pernyataan di atas memperlihatkan bagaimana organisasi Al berjejaring dengan organisasi lain namun berbeda saat menyikapi suatu permasalahan. Meskipun tergabung dalam satu forum yang terdiri dari berbagai organisasi masing-masing mem punyai visi dan misi yang berbeda, namun karena adanya isu bersama (colletive issue) maka menjadikan sebagai identitas bersama (colletive identity) dalam tercapainya tujuan bersama (goals).

Meskipun demikian organisasi Al juga menghadapi tantangan dalam jejaring sosial, mulai dari sulitnya pendanaan untuk mengadakan kegiatan yang mengundang atau bekerja sama dengan jaringan. Banyaknya pembubaran dan ancaman dari kelompok-kelompok tertentu jika menga dakan kegiatan terkait LBT dan LGBT, utamanya yang bersifat terbuka dan melibatkan banyak orang. Padahal, kegiatan semacam ini juga bisa menjadi sarana untuk memberikan pemahaman dan mengem bangkan jejaring sosial. Kemudian banyaknya upaya pelanggengan stigma bahwa LGBT (termasuk LBT) adalah penyimpangan, gangguan kejiwaan, dan pelaku kejahatan seksual terhadap anak sehingga individunya perlu disembuhkan dan organisasinya, yang dianggap melakukan propaganda, harus ditindak. Hal ini membuat sebagian individu LBT, utamanya yang sudah terbuka, kembali mendapat tekanan dari orang di sekitarnya, termasuk yang tadinya sudah bisa menerima. Mereka juga kemudian menjadi khawatir dan engan untuk terlibat dalam kegiatan-kegiatan yang diselenggarakan

${ }^{21}$ Hasil wawancara dengan Agustine (

Ardhanary Institute ) Hari Jumat, 20 Mei 2016 di FKM ( Fakultas Kesehatan Masyarakat ) Universitas Indonesia. 
organisasi. Di sisi lain, hal ini juga membuat sebagian mitra dari lembaga lain, utamanya lembaga non-LBT, yang tadinya sudah menerima dan paham atau masih ragu-ragu, menjadi bingung kembali, mempercayai stigma yang ada, dan enggan atau khawatir bekerja sama dengan organisasi ataupun individu LBT.

Sebagai organisasi LBT perempuan yang menggunakan pendekatan feminis, organisasi ini merupakan organisasi formal yang mempunyai visi, misi dan program kegiatan. Sebagai suatu gerakan sosial yang mengusung isu-isu kepentingan kaum LBT khususnya dan LGBT umumnya di Indonesia. Tidak akan mampu bertahan apabila tidak berusaha membangun jaringan-jaringan dengan berbagai pihak, baik secara langsung maupun tidak. Melalui relasi yang terjalin selama ini, menjadikan isu yang diusung sebagai isu yang sifatnya bersama (colletive issue) maka otomatis sebagai identitas bersama juga (colletive identity) dalam tercapainya tujuan bersama (goals).

Sebagaimana Agusyanto (1991) mengatakan bahwa jaringan sosial terbentuk dalam masyarakat karena pada dasarnya manusia tidak dapat berhubungan dengan semua manusia yang ada; hubungan selalu terbatas pada sejumlah orang tertentu. Setiap orang belajar dari pengalamannya untuk masing-masing memilih dan mengembangkan hubunganhubungan sosial yang terbatas jumlahnya dibandingkan dengan jumlah rangkaian hubungan sosial yang tersedia, disesuaikan dengan kebutuhan-kebutuhan yang ada pada individu bersangkutan sehingga dalam usaha peningkatan taraf hidup juga tidak menggunakan semua hubungan sosial yang dimilikinya. Hal tersebut sangat disadari oleh organisasi $\mathrm{Al}$, keterbatasan yang mereka miliki namun berusaha untuk membangun kekuatan relasi-relasi secara personal atau aktor melalui jaringan-jaringan yang ada. Masing-masing mereka memiliki keterba tasan dan kemampuan yang berbeda, namun mampu untuk saling melengkapi. Kekuatan dari masing-masing staf dalam organisasi ini juga disebabkan oleh pemimpin dari organisasi ini. Peran utama dari aktor pemimpin mempengaruhi eksistensi dari organisasi ini.
Saat ini dalam lingkungan gerakan perempuan nasional, siapa yang tidak mengenal organisasi Al. Organisasi yang memiliki gaung cukup luar biasa bagi gerakan perempuan LBT, mempengaruhi organisasi-organisasi LBT/LGBT daerahdaerah yang ada di Indonesia. Organisasi ini memulai "coming out" melalui dari dalam, khususnya pendiri sekaligus nakhoda organisasi ini yakni Agustine dan Lily. Selanjutnya diikuti staf yang ada dalam organisasi ini. Menurut saya, bahwa inilah organisasi yang secara utuh "coming out", baik secara kelembagaan maupun secara individual.

Pendekatan feminis yang digunakan organisasi ini melalui Agustine sangatlah memberi warna kental bagaimana organi sasi ini menyikapi suatu persoalan. Hal yang berbeda dilakukan Agustine bersama kawan-kawannya dalam organisasi ini. Proses dialogis lebih diutamakan Agustine dalam menyikapi pemberitaan akhir-akhir ini tentang LGBT di Indonesia. Pada umumnya gerakan organisasi perempuan feminis cendrung menggunakan metode aksi/ demonstrasi/ mobilisasi dalam memperjuang kan hak mereka. Bahkan metode ini merupakan metode utama dalam perjua ngan melawan penindasan, termasuk penindasan seksualitas.

Agustine bersama kawan-kawannya membangun organisasi sebagai alat perjuangan. Organisasi sebagai alat untuk mengumpulkan orang-orang yang seide dan mau berjuang bersama. Secara ideal normatif, organisasi yang terbangun seharus nya organisasi yang independen, mengedepankan kepentingan rakyat dan kaum tertindas dalam hal ini kaum yang tertindas secara seksual dan konsisten dalam berjuang.

Meskipun demikian, pastilah organisasi ini juga menghadapi tantangan, khususnya saat melakukan jejaring. Dalam kondisi sekarang yang semakin tidak memberi tempat bagi kaum LGBT di Indonesia, sangatlah mempengaruhi organi sasi ini berjejaring. Tantangan dalam jejaring sosial, mulai dari sulitnya pendanaan untuk mengadakan kegiatan yang mengundang atau bekerja sama dengan jaringan. Dan banyaknya pembubaran dan ancaman dari kelompok-kelompok tertentu jika menga dakan kegiatan terkait LBT dan LGBT, 
utamanya yang bersifat terbuka dan melibatkan banyak orang. Padahal, kegiatan semacam ini juga bisa menjadi sarana untuk memberikan pemahaman dan mengembang kan jejaring sosial.

Kemudian adanya upaya pelangge ngan stigma bahwa LGBT (termasuk LBT) adalah penyimpangan, gangguan kejiwaan, dan pelaku kejahatan seksual terhadap anak sehingga individunya perlu disembuh kan dan organisasinya, yang dianggap melakukan propaganda, harus ditindak. Hal ini membuat sebagian individu LBT, utamanya yang sudah terbuka, kembali mendapat tekanan dari orang di sekitarnya, termasuk yang tadinya sudah bisa menerima. Mereka juga kemudian menjadi khawatir dan engan untuk terlibat dalam kegiatan-kegiatan yang diselenggarakan organisasi. Di sisi lain, hal ini juga membuat sebagian mitra dari lembaga lain, utamanya lembaga non-LBT, yang tadinya sudah menerima dan paham atau masih ragu-ragu, menjadi bingung kembali, mempercayai stigma yang ada, dan enggan atau khawatir bekerja sama dengan organisasi ataupun individu LBT.

\section{E. Kesimpulan}

$\mathrm{K}$ ajian ini memahami organisasi LBT Ardhanary Institute "coming out" disebabkan adanya jaringan sosial yang telah dilakukan nya. Melalui aktor atau individu-individu dalam organisasi ini, yang telah melakukan relasi dengan aktor lainnya secara individual maupun lembaga. Pendekatan jaringan sosial timbul karena ada rasa ketidakpuasan dari para ahli antropologi terhadap pendekatan struktural fungsional (lihat Fedyani, dalam Agusyanto, 2007). Dari berbagai bahasan yang telah ada, dapat saya simpulkan sebagai berikut :
1. Situasi global sangat mempengaruhi eksistensi dari organisasi-organisasi LBT/LGBT di Indonesia. Organisasi Al "coming out" melalui dukungan jaringan sosial yang diberikan organisasi ini tidak hanya secara individu LBT namun juga bagi komunitas dan organisasi LBT /LGBT yang ada di daerah-daerah. Secara eksternal relasi sosial yang telah dilakukan Ardhanary Institute melalui beberapa lembaga (dalam dan luar negeri/internasional) atau individuindividu (aktor) secara langsung maupun tidak langsung.

2. Sebagai organisasi LBT yang telah "coming out" dimotori oleh individuindividu tergabung dalam organisasi ini. Aktor-aktor ini sebagai motivator, fasilitator, serta inspirator bagi kalangan lesbian yang ada di Indonesia. Tidak akan berlebihan jika saya menyimpulkan organisasi ini berimplikasi effek "struggling" bagi pergerakan organisasi LBT/LGBT di Indonesia. Agustine bersama teman-teman Ardhanary Institu te mampu mempengaruhi pergerakan organisasi LBT Perempuan lainnya yang ada di daerah-daerah.

3. Organisasi ini secara aktif membangun jaringan yang lebih luas melalui kerjasama dengan organisasi-organisasi perempuan lainnya, crisis center, penyedia layanan kesehatan, rumah aman, lembaga bantuan hukum dan Komnas Perempuan. Serta berusaha untuk membangun hubungan dengan para penegak hukum dalam memberikan pendampingan bagi LBT korban kekerasan. Di samping itu juga mewujud kan masyarakat agar dapat menerima kehadiran LBT di Indonesia.

\section{Daftar Pustaka}

Abelove, Henry, Michele Aina Barale, and David Halperin, eds.1993. The Lesbian and Gay Studies Reader. New York: Routledge

Agustine, Sri dan Evi LinaSutrisno.(eds.) 2013 Mendengar Suara Lesbian Indonesia: Kumpulan Buah Pikir Aktifis Feminis \& Pluralis. Ardhanary Institute - HIVOS ROSEA

Agustine. 2008 Makalah Gerakan LGBTIQ, Ardhanary Institute

Agusyanto, Ruddy. 2007 Jaringan Sosial dalam Organisasi. Penerbit PT. RajaGrafindo Persada, Jakarta 
Allen, J. 1990 Does Feminism Need a Theory of "The State"? In S.Watson (Ed,), Playing The State: Australian Feminist Intervention (hlm.21-38). London, New York:Verso.

Audre, Lorde. 1984. Sister Outsider. Crossing Press, New York

Armstrong, Elizabeth A.2002. Forging Gay Identities: Organizing Sexuality in San Francisco, 1950-1994. Chicago: University of Chicago Press

Atkinson, Jane Monnig. 1990 "How Gender Makes a difference in Wana Society." In Power and Difference: Gender in Island Southeast Asia. Jane Monnig Atkinson and Shelly Errington, eds., pp.59-93. Stanford: Stanford University Press

Bacchetta, Paola. 2002 "Rescaling Transnational 'queerdom': Lesbian and 'lesbian Identitary-positionalities in Delhi in the 1980s." Antipode: A Radical Journal of Geography 34(5): 947-973.

Behar, R., 1996 "Introduction: Out of Exile", dalam R. Behar dan D.Gordon (ed.), Women Writing Culture, Berkeley: University of California Press, 1-32.

Budianta,Melanie. 2002 "Transformasi Gerakan Perempuan di Indonesia", Horison Esai Indonesia Bunga Rampai

Bennett, Linda Rae. 2005. Women, Islam and Modernity: Single Women, Sexuality and Reproductive Health in Contemporary Indonesia. New York: Routledge Curzon

Bryman, Alan. 2004. Social Research Methods, second edition. Oxford: Oxford

Blackwood, Evelyn. 1998. "Tombois in West Sumatra: Constructing masculinity and erotic desire." Cultural Anthropology 13(4): 491-521. 56(2): 223-238. , 2000 "Culture and Women's Sexualities". Journal of Social Issues ,2002. "Reading Sexuality Across Cultures: Anthropology and Theories of Sexuality." In Out in Theory: The Emergence of Lesbian and Gay Anthropology. Ellen Lewin and William Leap, eds., pp. 69-92. Urbana: University of Illinois Press Indonesia."'Journal of Asian Studies 64(4): 849-879

2005b "Transnational sexualities in one place: Indonesian readings." Gender \&'Society 19(2): 221-242

2007 "Regulation of sexuality in Indonesian discourse: Normative gender, criminal law and shifting strategies of control." Culture, Health and Sexuality 9(3): 293-307

2008 "Transnational discourse and circuits of queer knowledge in Indonesia." GLQ: AJournal of Lesbian and Gay Studies14(4): 481-507

2009 "Trans identities and contingent masculinities: Being tombois in everyday practice." Feminist Studies 35(3): 454-480

2010a Falling into the Lesbi World: Desire and Difference in Indonesia. University of Hawaii Press.Also available through Hong Kong University Press, 2011

, 2010b "Lesbians," modernity and global translation: Female sexualities in Indonesia." In Routledge Handbook of Sexuality, Health and Rights. Peter Aggleton and Richard Parker, eds., pp. 69-76. London: Routledge

Blackwood, Evelyn and Saskia E. Wieringa. 2007 "Globalization, sexuality and silences: Women's sexualities and masculinities in an Asian context." In Women's Sexualities and Masculinities in a Globalizing Asia. Saskia E. Wieringa, Evelyn Blackwood and AbhaBhaiya, eds., pp. 1-20. New York: Palgrave Macmillan

Blackwood, Evelyn and Saskia E. Wieringa, eds. 1999 Female Desires: Same-Sex Relations and Transgender Practice Across Cultures. New York: Columbia University Press

Blackburn, Susan. 2009 "Perempuan dan Negara dalam Era Indonesia Modern", edisi terjemahan bahasa Indonesia.Penerbit : Yayasan Kalyanamitra. Maret.Jakarta

Boellstorff, Thomas

1999 "The perfect path: Gay men, marriage, Indonesia." GLQ: Journal of Lesbian and Gay Studies 5(4): 475-510 


Indonesia." American Anthropologist 107(4): $575-585$
,$-- 2005 b \quad$ The Gay Archipelago: Sexuality and Nation in Indonesia.
Princeton: Princeton University Press
Butler, Judith. 1990 Gender Trouble: Feminism and the Subversion of Identity. New
York: Routledge
and London: Routledge
- 1993 Sexuality Now: Embracing Diversity. USA: Wadsworth Cengage
Carrol, J. L. 2005 Learning

Davidson, C, G., Neale, J,M., Kring, A, M. 2002 Psikologi abnormal (9-ed). Jakarta: PT RajaGrafindo Persada

De Stuers, Cora Vreede. 2008 "Sejarah Perempuan Indonesia.Gerakan dan Pencapaian'.Edisi Terjemahan ke dalam bahasa Indonesia. Penerbit : Komunitas Bambu.Jakarta

Degenne, Alain \& Michel Forse. 1999 "Introducing Social Networks". SAGE Publications. London-Thousand Oaks-New Delhi

Douglass, Carol Anne. 1990 Love and Politics: Radical Feminist and Lesbian Theories, San Fransisco, California: Ism Press

Elliston, Deborah. 1995 "Erotic anthropology: 'Ritualized homosexuality' in Melanesia and beyond." American Ethnologist 22(4): 848-867.

-, 1999 "Negotiating transnational sexual economies: Female māhū and same-sex sexuality in 'Tahiti and her islands." In Female Desires: Same-sex Relations and Transgender Practices across Cultures. Evelyn Blackwood and Saskia E. Wieringa, eds., pp. 232-252. New York: Columbia University Press

Errington, Shelly. 1990 "Recasting sex, gender, and power: A theoretical and regional overview." In Power and Difference: Gender in Island Southeast Asia. Jane Monnig Atkinson and Shelly Errington, eds., pp. 1-58. Stanford: Stanford University Press

Foucault, Michel. 2008 La Volonte de Savoir :Histoire de la Sexualite. Ingin Tahu Sejarah Seksualitas. Yayasan Obor Indonesia FIB Universitas Indonesia Forum Jakarta Paris

1995 "Discipline \& Punish : The Birth of the Prison". Vintage Books A Division of Random House, Inc.New York

"The History of Sexuality". Vol. 1: An Introduction. New York: Vintage

Gayatri,B.J.D. 1996 "Indonesian lesbians writing their own script: Issues of feminism and Sexuality". In Amazon to Zami: Towards a Global Lesbian Feminism. Moniker Reinfelder, ed., pp. 86-97. London: Cassell

Gopinath, Gayatri. 1998 "Homo-economics: Queer sexualities in a transnational frame." In Burning Down the House: Recycling Domesticity. Rosemary Marangoly George, ed., pp. 102-124. Boulder: Westview Press

, 2005. Impossible Desires: Queer Diasporas and South Asian Public Cultures. Durham: Duke University Press

"Queer regions: Locating lesbians in Sancharram." In A Companion to Lesbian, Gay, Bisexual, Transgender, and Queer Studies. George Haggerty and Molly McGarry, eds., pp. 341-354. New York: Blackwell Publishers

Gonda, Caroline. 2009 Teori Lesbian. Dalam Pengantar Teori-Teori Feminis Kontemporer. (ed). Stevi Jackson dan Jackie Jones. Jalasutra Yogyakarta dan Bandung

Haggerty, George and Molly McGarry, eds.. 2007 A Companion to Lesbian, Gay, Bisexual, Transgender, and Queer Studies. New York: Blackwell Publishers

Herdt, Gilbert, ed. 1993 Third Sex, Third Gender: Beyond Sexual Dimorphism in Culture and History. New York: Zone Books

Jackson, Stevi, dkk. 2009 Pengantar Teori-Teori Feminis Kontemporer. Jalasutra Yogyakarta dan Bandung

Jurnal Perempuan. Seksualitas Lesbian. No.58 Jakarta, Maret 2008. 
Johnson, Mark, Peter Jackson and Gilbert Herdt. 2000 "Critical regionalities and the study of gender and sexual diversity in South East and East Asia."Culture, Health and Sexuality 2(4): 361-375.

Lai, Franco. 2007 "Lesbian masculinities: Identity and body construction among tomboys in Hong Kong." In Women's Sexualities and Masculinities in a Globalizing Asia.Saskia E. Wieringa, Evelyn Blackwood and AbhaBhaiya, eds., pp. 159-180. New York: Palgrave Macmillan

Martyn, Elizabeth. 2005The Women's Movement in Post-colonial Indonesia, Gender and Nation in a New Democracy. London: RoutledgeCurzon

M. Jacqui, Alexander and Chandra T. Mohanty, eds. 1997 Feminist Genealogies, Colonial Legacies, Democratic Futures. New York: Routledge

M. Jacqui, Alexander. 1991 "Redrafting morality: The postcolonial state and the Sexual Offences Bill of Trinidad and Tobago." In Third World Women and the Politics of Feminism, Chandra T. Mohanty, Ann Russo, and Lourdes Torres, eds., pp. 133-152. Bloomington: Indiana University Press

Mitchell, J.Clyde. 1969 Social Networks in Urban Situation ; Analysis of Personal Relationship in Central African Town. Institute for Social Research University of Zambia by Manchester University Press

Murchison, J.M. 2010 Ethnography Essentials : Designing, Conducting, and Presenting Your Research. San Francisco: Jossey-Bass

Moore, Henrietta L. $1994 \quad$ A Passion for Difference: Essays in Anthropology and Gender. Bloomington: University of Indiana Press

Murray, Sarah E. 1994 'Dragon ladies, draggin' men: Some reflections on gender, drag and homosexual communities." Public Culture 6: 343-363.

Muthmainnah, Yulianti. 2015 Hak Azasi Manusia LGBT dalam Kebijakan Dalam Negeri Indonesia, dalam Jurnal Perempuan Vol.20, No.4, November.

Oetomo, Dede. 1987 "Homoseksualitas di Barat dan di Indonesia" (Homosexuality in the West and in Indonesia). GAYa Nusantara 1(1): 9-20.

", 1996 "Gender and Sexual Orientation in Indonesia." In Fantasizing the Feminine in Indonesia. Laurie Sears, ed., pp. 259-269. Durham: Duke University Press

----------, 2001 Memberi Suara Pada Yang Bisu. Yogyakarta: Galang Press

Peletz, Michael G. 2006 "Transgenderism and gender pluralism in southeast Asia since early modern times."Current Anthropology 47: 309-340. York: Routledge

Phillips, Richard, Diane Watt and David Shuttleton, eds. 2000 De-centring Sexualities: Politics and Representations beyond the Metropolis. London: Routledge

PKWG UI. 2013 Profil PKWG UI: Mendekatkan Perempuan Kepada Keadilan Hukum dan Keadilan Sosial. Jakarta: Penerbit Pusat Kajian Wanita dan Gender Universitas Indonesia

Reinharz, Shulamit. 2005 Metode-Metode Feminis dalam Penelitian Sosial. Women Research Institute.Indonesia

Richardson, Diane and Steven Seidman, eds. 2002 Handbook of Lesbian and Gay Studies. London: Sage Publications

Rich, Adrianne, 1986 "Compulsory heterosexuality and lesbian existence", dalam Blood, Bread, and Poetry, New York:W.W.Norton

Rosaldo, MZ. 1974 "Woman, Culture, and Society: A Theoretical Overview", dalam M.Z. Rosaldo dan L. Lamphere (eds.) Woman. Culture \& Society. Stanford, California: Stanford University Press. HIm.17-42

Ryan Korbarri, Joseph. 2014 Sejarah Hari Solidaritas LGBT Nasional, dalam blog PLUS tanggal 28 Februari 2014

Setyawati, Sri. 2009 "Kaum Lesbians Pada Masyarakat Minangkabau : "Coming Out" 
Terhadap Identitas Seksual". Dalam buku Memoriam Prof.Dr.Khaidir Anwar, Ilmuwan Sederhana Nan Bersahaja. Fakultas Sastra Universitas Andalas.Padang

Spencer, Colin. 2004 Sejarah Homoseksualitas : Dari Zaman Kuno Hingga Sekarang. Kreasi Wacana : Yogyakarta.

Suryakusuma, Julia I. 2004 "Seksualitas dalam Pengaturan Negara" dalam Liza Hadiz (ed.) Perempuan dalam Wacana Politik Orde Baru, Pilihan Artikel Prisma. Jakarta: LP3ES. HIm. 354-377

Travis, Cheryl Brown,dkk. 2002 Sexuality, Society, and Feminism.American Psychological Association Washington, DC.

Tsing, Anna Lowenhaupt. 2004 "Global Connections'.Cultural Anthropology, Vol.15 (3), hal.327-360

\section{$\mathrm{NJ}$ :Princeton University Press}

Turner, Ralph. 1982 "Collective Behaviour and Recource Mobilisation as Approach to Social Movements: Issues and Continuities", dalam L.Kriesberg (ed), Research in Social Movements: Conflicts and Change, Vol.4.Greenwich: JAI Press, hlm.5.

Touraine,Alaine. 1988 Return of the Actor: Social Theory in Post Industrial Societ. Minneapolis: University of Minnesota Press.

Tribowo,D. $2006 \quad$ "Gerakan Perempuan Di Indonesia", dalam Gerakan Sosial Baru : Basis No.01-02,Tahun ke 55 Januari-Februari. Penerbit : Yayasan BP Basis, Yogyakarta

Tilly,Charles. 1978 "Social Movement and National Politics", dlm.C.Bright dan Sandra Harding (Eds). States-Making and Social Movements: Essays in History and Theory (Ann-Arbor,Michigan: University of Michigan Press,HIm:303-306

Vrede-de Stuers, Cora. 2008 Sejarah Perempuan Indonesia: Gerakan dan Pencapaian. Jakarta: Komunitas Bambu

Webster, Tracy Wright. 2008 "Re-articulations: Gender and Female Same-sex Subjectivities in Yogyakarta, Indonesia." Intersections: Gender and Sexuality in Asia and the Pacific 18. Available at http://intersections.anu.edu.au/issue18/wrightwebster.htm\#n32, accessed Jan. 18, 2009.

Wieringa, Saskia E. 1999 "Desiring bodies or defiant cultures: Butch-femme lesbians in Jakarta and Lima." In Female Desires: Same-sex Relations and Transgender Practices across Cultures. Evelyn Blackwood and Saskia E. Wieringa, eds., pp. 206231. New York: Columbia University Press

\section{Sexual Politics in Indonesia. New York: Palgrave Macmillan}

,2007."'If there is no feeling...': The dilemma between silence and coming out in a working-class butch/femme community in Jakarta".In Love and Globalization: Transformations of Intimacy in the Contemporary World. Mark Padilla, Jennifer S. Hirsch, Miguel Muñoz-Laboy, Robert E. Sember, and Richard G. Parker, eds., pp. 70-90. Nashville: Vanderbilt University PresS

, 1998“Kuntilanak Wangi : Organisasi-Organisasi Perempuan Indonesia Sesudah 1950". Kalyanamitra - Pusat Komunikasi dan Informasi Perempuan. Jakarta

dalam bahasa Jakarta

--------, 2013Lesbian Dalam Gerakan : Komunisme dan Praktik-Praktik Hubungan Seksual Sesama pada Era Pasca-Soeharto. Dalam Mendengar Suara Lesbian Indonesia : Kumpulan Buah Pikir Aktivis Feminis \& Pluralis. Editor : Sri Agustine \& Evi Lina Sutrisno. Penerbit : Ardhanary Institute - HIVOS ROSEA.Jakarta

Wieringa, Saskia E. dkk. 2007 "Hegemoni Hetero-Normativitas: Membongkar Seksualitas Perempuan Yang Terbungkam". Kartini Network

Wieringa, Saskia E. and Evelyn Blackwood. 1999"Intr oduction." In Female Desires: Samesex Relations and Transgender Practices across Cultures. Evelyn Blackwood and 
Saskia E. Wieringa, eds., pp. 1-38. New York: Columbia University Press

Wieringa, Saskia E. and Evelyn Blackwood, eds. 2009 Hasrat Perempuan: Relasi Seksual Sesama Perempuan dan Praktek Perempuan Transgender di Indonesia. Jakarta: Ardhanary Institute and HIVOS

Wieringa, Saskia E., Evelyn Blackwood and Abha Bhaiya, eds. 2007 Women's Sexualities and Masculinities in a Globalizing Asia. New York: Palgrave Macmillan

Women Research Institute. 2013 Afirmasi: Jurnal Pengembangan Pemikiran Feminis.Vol.02. Januari.Penerbit : WRI, Jakarta

Yulius, Hendri. 2016. Sejarah Gerakan Gay di Indonesia : Perdebatan tentang homoseksualitas pada 1980-an.www.rappler.com/indonesia/

Yolandasari, Ayu Regina. 2005 "Penyebab atau Penyembuh? Kekerasan Seksual Terhadap Lesbian, Biseksual, dan Transgender Female-to-Male di Indonesia". Dalam Jurnal Perempuan Vol.20, No.4, November.

Buletin Mahardhika. 2011 Komite Nasional Perempuan Mahardhika.Maret.Jakarta. 